\title{
タマネギ直播栽培における気温による展葉数推定法の検討
}

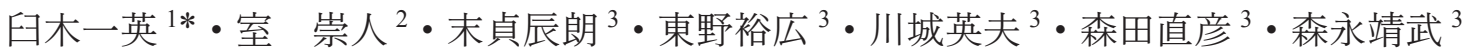 \\ 1 農業・食品産業技術総合研究機構北海道農業研究センタ一大規模畑作研究領域 \\ 082-0081 北海道河西郡芽室町新生南 \\ 2 農業・食品産業技術総合研究機構北海道農業研究センタ一作物開発研究領域 \\ 062-8555 北海道札幌市豊平区羊ヶ丘 \\ ${ }^{3} \mathrm{JA}$ 全農営農販売企画部営農・技術センタ一農産物商品開発室 254-0016 神奈川県平塚市東八幡
}

\section{Consideration of Methods to Estimate the Leaf Number of Direct Seeding Onions (Allium cepa L.) Using Air Temperature}

\author{
Kazuei Usuki ${ }^{*}$, Takato Muro ${ }^{2}$, Tatsuro Suesada ${ }^{3}$, Yasuhiro Higashino ${ }^{3}$, \\ Hideo Kawashiro $^{3}$, Naohiko Morita ${ }^{3}$ and Yasutake Morinaga ${ }^{3}$ \\ ${ }^{1}$ Large-scale Farming Research Division, Hokkaido Agricultural Research Center, NARO, \\ Shinseiminami, Memuro, Kasai, Hokkaido 082-0081 \\ ${ }^{2}$ Crop Breeding Division, Hokkaido Agricultural Research Center, NARO, Hitsujigaoka, Toyohira, Sapporo, Hokkaido $062-8555$ \\ ${ }^{3}$ Agricultural Research and Development Center, National Federation of Agricultural Cooperative Associations, \\ Higashiyawata, Hiratsuka, Kanagawa 254-0016
}

\begin{abstract}
The number of leaves on an onion plant, which is an important element of the yield, is related to the bulb diameter and weight. In order to estimate the number of leaves of an onion plant based on the accumulated temperature, we compared several calculation methods. The fitness of the estimation formula for a specific calculation method was verified by examining different variables: sowing date, cropping type, and method of phosphoric acid fertilization (broadcast or locally applied). As a result, the accuracy of the estimation method using the daily average temperature was lower than the triangle method and the average temperature method with a base temperature of $3.5^{\circ} \mathrm{C}$ or $5.0^{\circ} \mathrm{C}$. In addition, when the base temperature to calculate the effective temperature was set for the accumulated temperature method or triangle method, a base temperature of $5.0^{\circ} \mathrm{C}$ was more accurate than that of $3.5^{\circ} \mathrm{C}$. Therefore, our results indicate that the formula of the average temperature method with the base temperature set to $5.0^{\circ} \mathrm{C}$ is highly correlated with the effective temperature and number of leaves, and the prediction estimation error is small. In different cropping types, the average temperature method with a base temperature of $5.0^{\circ} \mathrm{C}$ was the most accurate. Based on our results, the estimation formula with the highest estimation accuracy is the average temperature method with a base temperature of $5.0^{\circ} \mathrm{C}$. However, further examination is required involving other varieties and regions, but the coefficient of the estimated formula suggests that onion plants develop 1.5 leaves per accumulated temperature above $5.0^{\circ} \mathrm{C}$ of $100^{\circ} \mathrm{C} \cdot$ day.
\end{abstract}

Key Words : accumulated temperature, local fertilization, triangle method

キーワード：局所施肥，三角法，積算温度

\section{緒 言}

タマネギ (Allium cepa L.) のりん茎形成は, 形態の異 なった数種の葉から構成された葉数の増加と各葉鞘の肥厚 によって行われる(青葉, 1964). タマネギの肥厚葉は, 貯蔵葉形成期に既に葉身がある葉の葉鞘が肥厚したもの で, りん茎肥大の開始時期に多くの葉数を持つ株は, 肥大 するりん茎が大きくなり易い（青葉，1951，1964）。 また，

2018 年 3 月 16 日 受付. 2018 年 6 月 22 日 受理. 本報告の一部は園芸学会平成 29 年度秋季大会で発表した.

* Corresponding author. E-mail: kazuei@affrc.go.jp
タマネギの春播き移植栽培では，葉身を持つ葉の数が年次 間や播種期の違いにより変動し，りん茎肥大の開始時期お よびりん茎重を左右する（山崎ら，2015）。これらの報告 は, タマネギの葉数がりん茥重に関わる重要な要素の 1 つ であることを示唆している.

Lancasterら（1996）は，基準温度を $5.0^{\circ} \mathrm{C}$ とる有効積算 温度が展葉と密接に関連することを示し, Brewster（2008） は, 基準温度 $3.5^{\circ} \mathrm{C}$ とする積算温度に比例して葉数が直線的 に増加することを認めた，積算温度の算出方法は，いくつ か提案されている（Lancaster ら，1996; 坂神・是永, 1981; Watanabe, 1978）が，これまでにタマネギの葉数を積算温 度から推定する場合に，複数の積算方法を比較して適合度 
を検討した報告は見られない. 作物は異なっているが，大 沼・佐々木（1993）は，ダイコン根重とハクサイ全重につ いて, 日平均気温の積算による值と三角法により算出した 温度を積算した值を用いた生育予測法を比較し, 三角法に よる積算温度を用いることで，収量との間により高い相関 が得られるとした．この三角法は，気温の日変化の影響を 考慮するために最低気温と最高気温を用いて 1 日当たりの 有効温度を計算する方法である（坂神・是永, 1981). 本 報告では，タマネギの生育指標として重要である葉数を気 温から推定することを目的として，三角法および日平均気 温を用いる平均気温法を比較した。

また，展葉数は，リン酸の直下施肥を行らことで，りん 茥の生育初期には $0.4 \sim 0.7$ 枚多くなる（臼木ら，2016）. このようにリン酸直下施肥は展葉を早める可能性がある. そこで, リン酸の全層施肥と直下施肥の違いが積算温度と 葉数の回帰式の係数に及ぼす影響を明らかにするとともに 秋播き栽培における台風遭遇の危険を避けた 3 回の播種日 と作型を異にする融雪後の春播き栽培に扣ける展葉数につ いても上記の回帰式の適合度を検証した.

\section{材料および方法}

\section{1. 栽培方法}

積算温度の算出方法を検討するために全農営農・技術 センタ一現地圃場（神奈川県茅ヶ崎市中島字向河内 1268 , 北緯 35.3, 東経 139.4, 標高 $2.5 \mathrm{~m}$ ）の褐色低地土圃場に打 いて 1 区 $0.5 \times 1.5 \mathrm{~m}$ の試験区を 4 反復分設けた。 また，異 なる作型における回帰式の適合度を検証するために, 秋播 きとした全農営農・技術センタ一現地圃場とは日平均気温 の推移が大きく異なる春播きを行った農業・食品産業技術 総合研究機北海道農業研究センター（北海道札幌市豊平区 羊ヶ丘 1 , 北緯 43.0, 東経 141.4 , 標高 $81.3 \mathrm{~m}$, 以下では北海 道農業研究センターと記載) と同センター芽室研究拠点 (北海道河西郡芽室町新生南 9, 北緯 42.9, 東経 143.1, 標高 $93.9 \mathrm{~m}$, 以下では芽室研究拠点と記載）の火山性土圃場に 扎いて 1 区 $0.5 \times 1.5 \mathrm{~m}$ の試験区を 3 反復分設けた.

タマネギは, ‘もみじ 3 号’ ((株)七宝) のコート種子を すべての圃場に抢いて供試した。全農営農・技術センター 現地圃場に打ける施肥は，2015 年 9 月 25 日に基肥，3 月 29 日に追肥を施用した。 基肥の全層施肥は，窒素 $(\mathrm{N})$, リ ン酸 $\left(\mathrm{P}_{2} \mathrm{O}_{5}\right)$ およびカリウム $\left(\mathrm{K}_{2} \mathrm{O}\right)$ を基肥としてそれぞれ 成分量で $10,30,10 \mathrm{~g} \cdot \mathrm{m}^{-2}$ 施用した. また, 直下施肥は, 末 貞ら（2018）の報告に従い, 窒素とカリウムを各 $10 \mathrm{~g} \cdot \mathrm{m}^{-2}$, リン酸 $20 \mathrm{~g} ・ \mathrm{~m}^{-2}$ を2015 年9月 25 日に全層施肥するとと もに播種時にリン酸 $10 \mathrm{~g} \cdot \mathrm{m}^{-2}$ を播種条の下方 $2 \sim 4 \mathrm{~cm}$, 幅 $4 \sim 5 \mathrm{~cm}$ に施肥した. 全層施肥に用いた肥料は, 化成 肥料（くみあい複合燐加安 42 号, ジェイカムアグリ (株) ) 扣よび過リン酸石灰（くみあい17.5 粒状過リン酸石灰, コープケミカル(株)）を混合して施用した. 直下施肥に用 いた肥料は，過リン酸石灰を施用した。 な执，全層施肥で
は, 肥料散布後にロータリー耕を行らことによって $0 \mathrm{~cm}$ から $20 \mathrm{~cm}$ の層を攪拌した．播種は, クリーンシーダ APS40C（アグリテクノ矢崎(株)）を用いて行った。全農営 農・技術センタ一現地圃場の播種は，秋播きのために台風 遭遇を避けた 10 月 8 日と 10 月 15 日, 10 月 21 日に行った. な掞，10月 21 日の播種の施肥方法は，全層施肥と直下施 肥を組み合わせた処理のみとした。追肥は，リン酸および カリウムが $3 \mathrm{~g} ・ \mathrm{~m}^{-2}$ となるよらに上記の化成肥料を手で表 層施肥した. 北海道農業研究センターに打ける施肥は, 2016 年 4 月 6 日に基肥を全層施肥，芽室研究拠点では, 2016 年 4 月 19 日に基肥を全層施肥した。北海道農業研究 センターに打ける基肥は, 窒素を $15 \mathrm{~g} ・ \mathrm{~m}^{-2}$, リン酸を $10 \mathrm{~g} ・ \mathrm{~m}^{-2}$ を施用した。用いた肥料は硫黄被覆尿素（SCU (M), サンアグロ(株)）を全層施肥するとともに，全農営 農・技術センタ一現地圃場と同じ方法を用いて，過リン酸 石灰を播種条の下方 $2 \sim 4 \mathrm{~cm}$ ，幅 $4 \sim 5 \mathrm{~cm}$ に施肥した．芽 室研究拠点に打ける基肥は, 窒素 $(\mathrm{N})$, リン酸 $\left(\mathrm{P}_{2} \mathrm{O}_{5}\right)$ お よびカリウム $\left(\mathrm{K}_{2} \mathrm{O}\right)$ をそれぞれ $15,45,15 \mathrm{~g} ・ \mathrm{~m}^{-2}$ 施用し た. 用いた肥料は，化成肥料（エーコープ苦土入り複合硝 加燐安 S131，ホクレン肥料(株)）を全層施肥した。加光 て，上記の方法を用いて過りン酸石灰を播種条の下方 2 $4 \mathrm{~cm}$, 幅 $4 \sim 5 \mathrm{~cm}$ に施肥した. な拉, 北海道農業研究セン ター抢よび芽室研究拠点に打いても全層への肥料散布後 は，ロータリー耕を行らことによって $0 \sim 20 \mathrm{~cm}$ の層を攪 拌した. 北海道農業研究センターに打ける播種はクリーン シーダAPS-40C を用いて，春播きのために融雪後の 2016 年 4 月 7 日, 芽室研究拠点は 2016 年 4 月 20 日に行った.

\section{2. 葉数調査の方法}

展葉数の調査は, 子葉を除き最初の本葉を第 1 葉として 展開した葉数を計数した。全農営農・技術センタ一現地圃 場の調査は, 2015 年 11 月 16 日を初回として 4 日から 26 日間ごと, 各処理 10 株を選び調査した. なお, 調査途中 で枯死した株や抽苔した株が出たので最終的には 6 株から 10 株の平均值を用いた. 北海道農業研究センターの調査 は，2016年 5 月 16 日抢よび 6 月 14 日，7月 23 日，芽室研 究拠点の調査は，2016年 5 月 16 日，6月 14 日，7月 23 日， 8 月 24 日に 10 株を選び調査した.

\section{3. 気温データ}

全農営農・技術センター現地圃場に括ける日平均気温抒 よび日最低気温, 日最高気温は, アメダス (辻堂) のデー タを利用した。また，北海道農業研究センターおよび芽室 研究拠点に打ける日平均気温括よび日最低気温, 日最高気 温は，それぞれの敷地内設置された気象観測露場のデータ を利用した。

\section{4. 温度の算定方法と適合度の検討方法}

三角法は，当日の最低気温から翌日の最低気温までを 1 日として $2 つ の$ 最低気温と最高気温を結ぶ 2 直線と発育 限界である基準温度に囲まれた部分を求積することによっ て得られる值を用いる方法である（坂神・是永, 1981). 
この三角法を用いた積算温度の算出は, 展葉の下限温度を 示す基準温度を Brewster（2008）の報告に従い $3.5^{\circ} \mathrm{C}$ も し

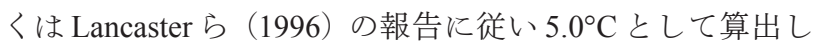
た有効温度を積算した（以下，三角法 $\left(3.5^{\circ} \mathrm{C}\right.$ ), 三角法 $\left(5.0^{\circ} \mathrm{C}\right)$ と表記)。な抢，発育限界の上限温度は設定しな かった. 平均気温法は, 基準温度 $3.5^{\circ} \mathrm{C}$ (Brewster, 2008),

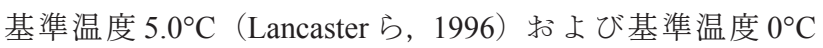
としてそのアメダスまたは気象観測露場の日平均気温との 差を積算した（以下，平均気温法 $\left(3.5^{\circ} \mathrm{C}\right)$, 平均気温法 $\left(5.0^{\circ} \mathrm{C}\right)$, 平均気温法 $\left(0^{\circ} \mathrm{C}\right)$ と表記). 求めた回帰式の適合 度は，それぞれの回帰式から推定した展葉数と実測値の間 の決定係数 $\left(\mathrm{R}^{2}\right)$ を用いて検証した。な执，積算温度は， 展葉数が概ね 1.0 であった調査初日（全農営農・技術セン タ一現地圃場 11 月 16 日もしくは 11 月 20 日, 北海道農業 研究センターおよび芽室研究拠点 5 月 16 日）を $0.0^{\circ} \mathrm{C} ・$ 日 として積算した. 回帰式を用いて求めた葉数の推定值と実 測值との間の適合度は, 決定係数执よび予測推定誤差であ る RMSE（Lancasterら，1996）により検証した. 推定のた めの回帰式の差の検定は, エクセル統計 2015 for Windows （R）（(株）社会情報サービス）を用いて共分散分析により 検定を行った.

\section{結 果}

\section{1. 秋播き直播タマネギの葉数と日平均気温との関係}

アメダス (辻堂) に打ける日平均気温の推移は, 短期的 には平年值を大きく上回る日が出現したが，1 月下旬を最 低としてその後に上昇する推移を示した（第 1 図）．1 日当 たりの展葉数は， 12 月から 2 月には 1 日当たり 0.1 枚以下 であったが, 気温の変化に伴い 3 月以降には最大 0.2 枚程 度まで上昇した (第 1 図). しかし，1日当たりの展葉数 は, 肥大が始まったと推定される5月中旬以降には再び 0.1 枚以下に低下した (第 1 図). 日平均気温が $5.0^{\circ} \mathrm{C}$ 以下 に低下した日は，播種日の 10 月 8 日から最後の調査日の 5 月 25 日までの間に 7 日，そのらち $3.5^{\circ} \mathrm{C}$ 以下に低下したの は2 日のみであった（第1図）。

積算温度と葉数との回帰式の決定係数は, $0.968 \sim 0.988$
の有意 $(\mathrm{p}<0.01)$ な值を示した（第 2 図）．各回帰式の決 定係数に及ぼす積算温度の算定方法の影響は, 10 月 8 日 播種の全層施肥では展葉の基準温度を $0^{\circ} \mathrm{C}$ とた平均気温 法 $\left(0{ }^{\circ} \mathrm{C}\right)$ の決定係数が 0.968 となり, 三角法や平均気温 法の $0.981 〜 0.988$ を下回った（第 2 図）。な扣，基準温度 を $5.0^{\circ} \mathrm{C}$ とた三角法や平均気温法の決定係数は, $3.5^{\circ} \mathrm{C}$ とした場合よりもわずかに上回った，りん茥の肥大開始で ある播種後 208 日目の展葉数は 14.9 枚であったのに対し て, 三角法 $\left(3.5^{\circ} \mathrm{C}\right)$ の推定值は 14.0 枚, 三角法 $\left(5.0^{\circ} \mathrm{C}\right)$ は 14.4 枚, 平均気温法 $\left(3.5^{\circ} \mathrm{C}\right)$ は 13.5 枚, 平均気温法 $\left(5.0^{\circ} \mathrm{C}\right)$ は 14.0 枚, 平均気温法 $\left(0^{\circ} \mathrm{C}\right)$ は 13.4 枚であった.

全層施肥と直下施肥の違いが回帰式の傾きと切片に及ぼ す影響について共分散分析を用いて検討した結果，傾きと 切片は, 全層施肥と直下施肥の間に差が認められなかった (データ省略)，従って，実測值と全層施肥の場合における 回帰式から推定した展葉数との間の決定係数抏よび予測推 定誤差であるRMSEを比較した（第 1 表），展葉数の実測 值と推定值との間の決定係数はいずれの回帰式でも 0.965 $(\mathrm{p}<0.01)$ 以上を示した.

\section{2. 異なる播種日における秋播き直播タマネギの展葉数へ の回帰式の適用}

播種時期の違いが回帰式の適合度に及ぼす影響を検討し た結果，全層施肥の 10 月 15 日播種における葉数の実測值 と推定值との間の決定係数はいずれの回帰式でも平均気温 法 $\left(0^{\circ} \mathrm{C}\right)$ の值を上回った (第 2 表). RMSE は，平均気温 法 $\left(5.0^{\circ} \mathrm{C}\right)$ が最も小さかった。直下施肥の 10 月 15 日扎よ び21 日播種に扣ける葉数の実測值と推定值との間の決定 係数はいずれの回帰式でも日平均気温法 $\left(0^{\circ} \mathrm{C}\right)$ の值を上 回った，RMSEは，10月 15 日および 10 月 21 日播種では平 均気温法 $\left(5.0^{\circ} \mathrm{C}\right)$ が最も小さかった.

\section{3. 春播き直播タマネギの葉数への回帰式の適用}

北海道農業研究センターおよび芽室研究拠点の生育期間 の日平均気温は，8月上旬に向けて上昇し，芽室研究拠点 で日々の振れ幅が大きかった（第 3 図）．北海道農業研究 センターでは, 播種日の 4 月 7 日から最後の調査日 7 月 23 日までの間に日平均気温が $5.0^{\circ} \mathrm{C}$ 以下に低下した日は 6 日,

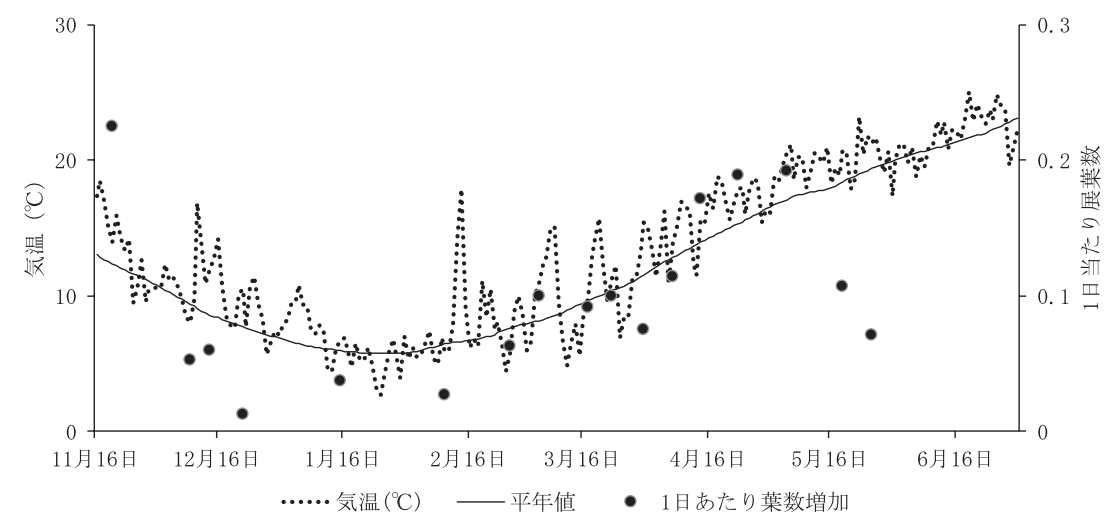

第 1 図 アメダス (辻堂) の日平均気温と平年值, 全農営農・技術センタ一現地圃場に拈けるタマネギの 1 日当たり展葉数 

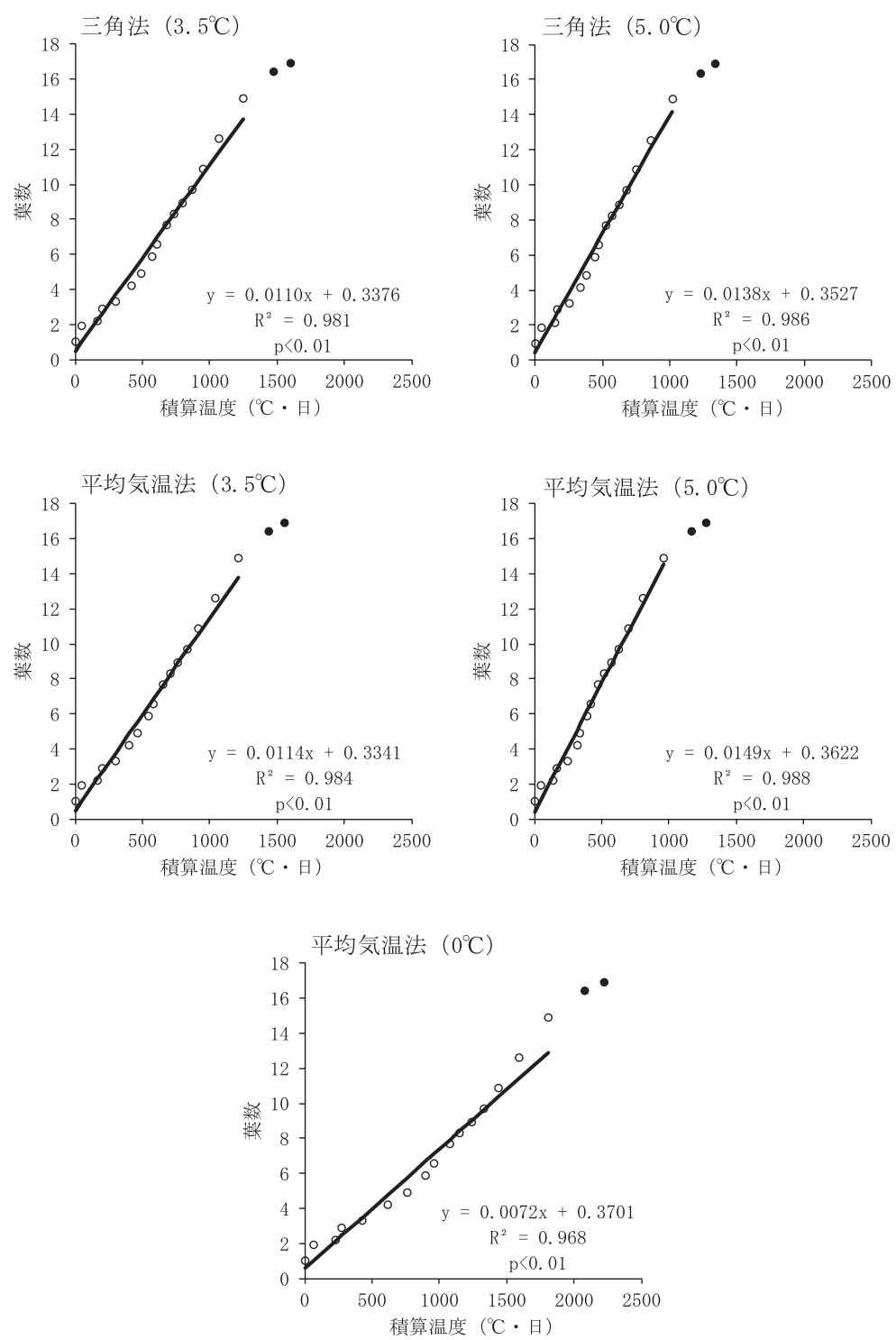

第2 図 全層施肥に打積算温度とタマネギの展葉数との関係 ○は第 1 葉から肥大開始まで，○は肥大開始以降を示す 回帰式拉よび決定係数の算出は第 1 葉から肥大開始までの值を用いた

第 1 表 積算温度算出方法の違いが直下施肥を行ったタマ ネギの葉数の実測值と予測值との間の決定係数および RMSE に及活す影響

\begin{tabular}{cccccc}
\hline \hline & \multicolumn{5}{c}{$10 / 8$ 直下施肥 } \\
\cline { 2 - 6 } & $\begin{array}{c}\text { 三角法 } \\
\left(3.5^{\circ} \mathrm{C}\right)\end{array}$ & $\begin{array}{c}\text { 三角法 } \\
\left(5.0^{\circ} \mathrm{C}\right)\end{array}$ & $\begin{array}{c}\text { 平均 } \\
\text { 気温法 } \\
\left(3.5^{\circ} \mathrm{C}\right)\end{array}$ & $\begin{array}{c}\text { 牙均温法 } \\
\left(5.0^{\circ} \mathrm{C}\right)\end{array}$ & $\begin{array}{c}\text { 平均 } \\
\left(0^{\circ} \mathrm{C}\right)\end{array}$ \\
\hline $\begin{array}{c}\text { 決定係数 } \\
\left(\mathrm{R}^{2}\right)\end{array}$ & 0.977 & 0.982 & 0.980 & 0.984 & 0.965 \\
$\mathrm{RMSE}$ & 0.150 & 0.131 & 0.141 & 0.128 & 0.183 \\
\hline
\end{tabular}

そのらち $3.5^{\circ} \mathrm{C}$ 以下に低下したのは 2 日のみであった（第 3 図). 芽室研究拠点では, 播種日の 4 月 21 日から最後の 調査日の 8 月 24 日までの間に日平均気温が $5.0^{\circ} \mathrm{C}$ 以下に低
下した日は 4 日，そのらち $3.5^{\circ} \mathrm{C}$ 以下に低下したのは 2 日 のみであった（第3図）。北海道農業研究センターでは, 実測值と推定值との間の決定係数は, 平均気温法 $\left(0^{\circ} \mathrm{C}\right)$ と比べて，三角法や平均気温法 $\left(3.5^{\circ} \mathrm{C}\right.$ および $\left.5.0^{\circ} \mathrm{C}\right)$ が上 回り, 三角法 $\left(5.0^{\circ} \mathrm{C}\right)$ と平均気温法 $\left(5.0^{\circ} \mathrm{C}\right)$ が大きかっ た（第 3 表）。一方， RMSEは，三角法 $\left(3.5^{\circ} \mathrm{C}\right)$ が最も小 さかった.

芽室研究拠点では，実測値と推定值との間の決定係数 は, 日平均気温法 $\left(0^{\circ} \mathrm{C}\right)$ と比べて, 三角法 $\left(3.5^{\circ} \mathrm{C}\right)$ や平 均気温法 $\left(3.5^{\circ} \mathrm{C}\right.$ 打よび $\left.5.0^{\circ} \mathrm{C}\right)$ が上回り，また， RMSEは 三角法 $\left(3.5^{\circ} \mathrm{C}\right)$ が最も小さかった（第 3 表）.

\section{考察}

青葉（1951）は，タマネギの摘葉による影響を調査し， 
第 2 表 積算温度算出方法の違いが播種日の異なるタマネギの葉数の実測值と予測值との間の決定係数およびRMSEに及ぼす影響

\begin{tabular}{|c|c|c|c|c|c|c|c|c|c|c|c|c|c|c|c|}
\hline & \multicolumn{5}{|c|}{ 10/15 全層施肥 } & \multicolumn{5}{|c|}{ 10/15 直下施肥 } & \multicolumn{5}{|c|}{ 10/21 直下施肥 } \\
\hline & $\frac{\text { 三角法 }}{\left(3.5^{\circ} \mathrm{C}\right)}$ & $\begin{array}{l}\text { 三角法 } \\
\left(5.0^{\circ} \mathrm{C}\right)\end{array}$ & $\begin{array}{l}\text { 平均 } \\
\text { 気温法 } \\
\left(3.5^{\circ} \mathrm{C}\right)\end{array}$ & $\begin{array}{l}\text { 平均 } \\
\text { 気温法 } \\
\left(5.0^{\circ} \mathrm{C}\right)\end{array}$ & $\begin{array}{c}\text { 平均 } \\
\text { 気温法 } \\
\left(0^{\circ} \mathrm{C}\right)\end{array}$ & $\frac{\text { 三角法 }}{\left(3.5^{\circ} \mathrm{C}\right)}$ & $\begin{array}{l}\text { 三角法 } \\
\left(5.0^{\circ} \mathrm{C}\right)\end{array}$ & $\begin{array}{l}\text { 平均 } \\
\text { 気温法 } \\
\left(3.5^{\circ} \mathrm{C}\right)\end{array}$ & $\begin{array}{l}\text { 平均 } \\
\text { 気温法 } \\
\left(5.0^{\circ} \mathrm{C}\right)\end{array}$ & $\begin{array}{c}\text { 平均 } \\
\text { 気温法 } \\
\left(0^{\circ} \mathrm{C}\right)\end{array}$ & $\begin{array}{l}\text { 三角法 } \\
\left(3.5^{\circ} \mathrm{C}\right)\end{array}$ & $\begin{array}{l}\text { 三角法 } \\
\left(5.0^{\circ} \mathrm{C}\right)\end{array}$ & $\begin{array}{l}\text { 平均 } \\
\text { 気温法 } \\
\left(3.5^{\circ} \mathrm{C}\right)\end{array}$ & $\begin{array}{l}\text { 平均 } \\
\text { 気温法 } \\
\left(5.0^{\circ} \mathrm{C}\right)\end{array}$ & $\begin{array}{c}\text { 平均 } \\
\text { 気温法 } \\
\left(0^{\circ} \mathrm{C}\right)\end{array}$ \\
\hline $\begin{array}{c}\text { 決定係数 } \\
\left(\mathrm{R}^{2}\right)\end{array}$ & 0.978 & 0.986 & 0.982 & 0.990 & 0.961 & 0.972 & 0.980 & 0.976 & 0.984 & 0.956 & 0.964 & 0.974 & 0.968 & 0.980 & 0.942 \\
\hline RMSE & 0.223 & 0.199 & 0.137 & 0.109 & 0.248 & 0.245 & 0.223 & 0.235 & 0.220 & 0.267 & 0.308 & 0.271 & 0.293 & 0.139 & 0.349 \\
\hline
\end{tabular}

第 3 表 積算温度算出方法の違いが北海道農業研究センターおよび芽室研究拠点に扣けるタマネギの葉数の実測值と 予測值との間の決定係数およびRMSEに及ぼす影響

\begin{tabular}{|c|c|c|c|c|c|c|c|c|c|c|}
\hline & \multicolumn{5}{|c|}{ 北海道農業研究センター } & \multicolumn{5}{|c|}{ 芽室研究拠点 } \\
\hline & $\begin{array}{l}\text { 三角法 } \\
\left(3.5^{\circ} \mathrm{C}\right)\end{array}$ & $\begin{array}{l}\text { 三角法 } \\
\left(5.0^{\circ} \mathrm{C}\right)\end{array}$ & $\begin{array}{l}\text { 平均 } \\
\text { 気温法 } \\
\left(3.5^{\circ} \mathrm{C}\right)\end{array}$ & $\begin{array}{l}\text { 平均 } \\
\text { 気温法 } \\
\left(5.0^{\circ} \mathrm{C}\right)\end{array}$ & $\begin{array}{c}\text { 平均 } \\
\text { 気温法 } \\
\left(0^{\circ} \mathrm{C}\right)\end{array}$ & $\begin{array}{l}\text { 三角法 } \\
\left(3.5^{\circ} \mathrm{C}\right)\end{array}$ & $\frac{\text { 三角法 }}{\left(5.0^{\circ} \mathrm{C}\right)}$ & $\begin{array}{c}\text { 平均 } \\
\text { 気温法 } \\
\left(3.5^{\circ} \mathrm{C}\right)\end{array}$ & $\begin{array}{c}\text { 平均 } \\
\text { 気温法 } \\
\left(5.0^{\circ} \mathrm{C}\right)\end{array}$ & $\begin{array}{c}\text { 平均 } \\
\text { 気温法 } \\
\left(0^{\circ} \mathrm{C}\right)\end{array}$ \\
\hline $\begin{array}{c}\text { 決定係数 } \\
\left(\mathrm{R}^{2}\right)\end{array}$ & 0.998 & 0.999 & 0.998 & 0.999 & 0.996 & 0.998 & 0.997 & 0.998 & 0.998 & 0.997 \\
\hline RMSE & 0.222 & 0.438 & 0.223 & 0.578 & 0.655 & 1.004 & 1.530 & 1.041 & 1.073 & 1.261 \\
\hline
\end{tabular}

栄養成長期の展葉数とりん茎重との間には正の相関がある ことを明らかにした。 また, Lancasterら（1996）は, りん 片の肥厚が開始された後の葉数が肥厚開始までの生育期間 の長さに伴い減少することを明らかにした. これらの報告 は, りん茎の肥大開始までの生育が倒伏までの葉数に影響 を及洁すことを示唆している。また，倒伏までの葉数は， りん茎重との間に正の相関が認められることが明らかにさ れている(臼木・室，2018）。これらは，葉数の多少がり ん茎重に影響を及ぼすことを示し，葉数を推定すること は，生育やりん茎重の良否を考光るら光で有効な指標とな ると考光られる. 末貞ら (2018) は, タマネギの直播栽培 に打いて葉数と積算温度との間に有意な相関が認められた ことから倒伏時に一定の葉数へ到達するための播種日の推 定が積算温度を用いてできると考兄, 移植栽培と同じ展葉 数を確保する播種日の推定を行った. しかし，末貞ら
（2018）の報告では出芽前の展葉が見られない時期も同じ 回帰式で推定している. 播種から出芽までに有効積算地温 (基準温度 $1.4^{\circ} \mathrm{C}$ ） $219^{\circ} \mathrm{C} ・$ 日であることが報告されている (Bierhuizen - Wagenvoort, 1974; Wagenvoort・Bierhuizen, 1977)。これらの報告の地温や積算温度は, 葉数が積算温 度に比例して直線的に増加するとされる $3.5^{\circ} \mathrm{C}$ から $23.0^{\circ} \mathrm{C}$ (Brewster, 2008）の日平均気温や日々の積算温度とは異な ると考兄られる，そのため播種から出芽もしくは第 1 葉が 展葉するまでと第 1 葉の展葉以降では異なる回帰式を適用 すべきである，な括，末貞ら（2018）の回帰式では傾きが 0.0071 であるのに対して, 本報告では用いた品種に違いが あるが，傾きが $0.0072 \sim 0.0149$ のやや上向きの回帰式と なった (第 2 図)、本報告に打いて, いずれの積算温度の 算出方法による回帰式を用いても決定係数は高く, 第 1 葉 以降の展葉数は基準温度を設定した積算温度に強く依存す

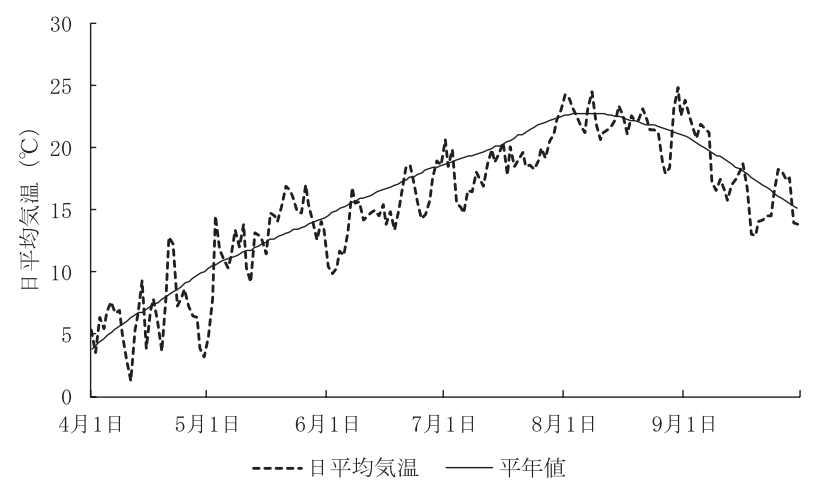

北海道農業研究センター

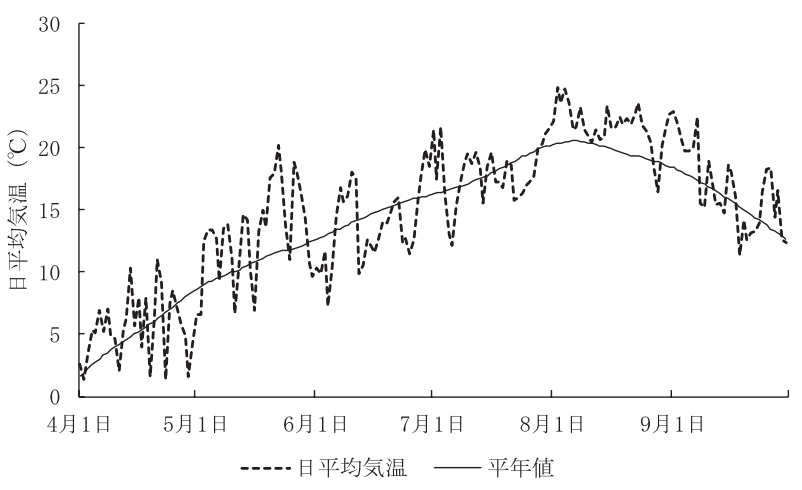

芽室研究拠点

第 3 図 北海道農業研究センターおよび芽室研究拠点の気象観測露場の日平均気温と平年值 
ると考えられた（第 2 図）。また，日平均気温が基準温度 を下回る日が少ない栽培条件では, 積算温度の算出方法の 違いは小さいと考光られた。 リン酸直下施肥を行った場合 でも回帰式の傾きと切片は, 全層施肥との間に差が認めら れなかった。な牧，臼木ら（2016）は，土壌の可給態リン 酸含量が低い圃場でリン酸直下施肥を行う場合には出芽後 の展葉が早まり, $2 \sim 3$ 葉期の葉数は, $0.4 \sim 0.7$ 枚多くな るが, 本解析では葉数の差は, $0 \sim 0.1$ 枚しか生じていな かった．全層施肥のデータを用いて作成した回帰式によっ て推定した葉数と直下施肥を行った場合の葉数の実測値と の間の決定係数は高く $(\mathrm{p}<0.01), \mathrm{RMSE}$ は, $0.128 \sim 0.183$ と差がわずかであり, リン酸直下施肥は, 出芽から第 1 葉 までの展葉には影響があるが, 第 1 葉からりん茎肥大まで の生育期間中の展葉と積算温度との関係に影響を及ぼさな いと考光られた。 しかし, 本解析では検討しなかった播種 から第 1 2葉までの期間について, 土壤肥沃度やリン酸 の直下施肥を用いた減肥栽培（臼木ら，2017）が播種から 第 $1 \sim 2$ 葉までの展葉と日平均気温との関係に及活す影響 については，解析が必要であると考兄られた。

全農営農・技術センター現地戋場に打政る 10 月 8 日播 種の全層施肥に抢けるデータから算出した回帰式を用い, 10 月 15 日播種のデータを入力して得られた推定值と実測 值との間の決定係数を比較した. それらの決定係数は, 展 葉の基準温度を設定した回帰式では基準温度を $0^{\circ} \mathrm{C}$ とた 平均気温法 $\left(0^{\circ} \mathrm{C}\right)$ を上回った (第 2 表)。また, RMSEは, 三角法 $\left(5.0^{\circ} \mathrm{C}\right)$ が最も小さかった。 全農営農・技術セン ター現地戋場とは作型が異なる北海道農業研究センターお よび芽室研究拠点では, 推定值と実測值との間に認められ た決定係数は, いずれの回帰式でも $0.996(\mathrm{p}<0.01)$ 以上 を示した (第2 表). RMSE は, 北海道農業研究センター 扣よび芽室研究拠点では三角法 $\left(3.5^{\circ} \mathrm{C}\right)$ が最も小さかっ た. 北海道農業研究センターと比べて芽室研究拠点の RMSEが大きい值を示したが，2016年は 8 月に相次いで 4 つの台風が北海道に上陸もしくは接近した（広田，2017）。 芽室研究拠点のRMSE は, タマネギが冠水の被害にあっ たことによって影響された可能性がある. 以上のことか ら, 推定精度は, 秋播き直播栽培では播種日が異なる場合 に扎いても施肥方法に関わらず平均気温法 $\left(5.0^{\circ} \mathrm{C}\right)$ に拉 いて決定係数が高く, RMSE も小さいことが示唆された. また，春播き直播栽培である北海道農業研究センタ一およ び芽室研究拠点では, 平均気温法 $\left(5.0^{\circ} \mathrm{C}\right)$ 飞打いて決定 係数が高い(第 3 表). 芽室研究拠点では RMSEが大きい 傾向にあるが, 播種日や作型の違いがあっても安定的に展 葉数の推定精度が高い回帰式は, 平均気温法 $\left(5.0^{\circ} \mathrm{C}\right)$ で あると判断できた.

Lancaster ら（1996）は，出芽から肥大までの間に基準温 度 $5.0^{\circ} \mathrm{C}$ とした積算温度 $100^{\circ} \mathrm{C}$ ・日当たりに 1.02 枚の葉が 展開することを明らかにした。 全層施肥に打ける平均気温 法 $\left(5.0^{\circ} \mathrm{C}\right)$ の回帰式の係数から算出した積算温度 $100^{\circ} \mathrm{C} \cdot$
日当たりの展葉は, 1.49 枚であり, Lancasterら（1996）が 示した值よりも大きい。ささらに他品種や他地域での検討を 必要とするが，タマネギ品種 ‘夕夕じ 3 号” は，概和積算 温度 $100^{\circ} \mathrm{C}$ ・日（基準温度 $5.0^{\circ} \mathrm{C}$ ）当たりに約 1.5 枚の展葉 が認められると考兄られた。本報告に拀いて，1 日当たり の展葉数は，12月中旬～ 2 月上旬の低温期には少なく, 2 月上旬以降に多くなった (第 1 図)。また，1 日当たりの展 葉数は, 肥大が始まった 5 月以降には 0.1 枚以下に低下し た (第 1 図)。本解析に颃いては第 1 葉から肥大開始まで の葉数について検討したが，今後は，播種から第 1 葉期ま での展葉拈よびりん茎の肥大開始後の積算温度を用いた葉 数推定を行らこと, ならびに生育期間を通じて展葉に影響 すると考兄ら水る土壤水分や日射量, 土塞肥沃度, 施肥方 法などが回帰式に及湆す影響について検討する必要が ある.

10 月 8 日播種の全層施肥では, りん茎の肥大開始であ る播種後 208 日目の展葉数が実測で 14.9 枚であったのに 対して平均気温法 $\left(5.0^{\circ} \mathrm{C}\right)$ では 14.0 枚を示し, 概初葉数 を推定できた，日平均気温の平年值を用い，求められる葉 数に必要な積算温度を算出することで移植栽培と同等の葉 数を確保できる播種日が推定可能となる. このように本報 告で示した積算温度 $100^{\circ} \mathrm{C} ・$ 日（基準温度 $5.0^{\circ} \mathrm{C}$ ）当たり に約 1.5 枚の展葉が認められる回帰式の利用は, 多様な気 象条件下や地域でタマネギの直播栽培する際に, 播種期決 定への活用の他, 品種の早晚性の評価（室ら，2017）や収 量性の判断（巨白・室，2018）への利用が期待できる. Brewsterら（1977）は，タマネギの秋播き栽培で越冬時の 植物体の大きさが抽苔や越冬率に影響を及洔すことを明ら かにしている. 山崎・田中（2005）は，同じAllium属のネ ギの花芽分化が可能な生育量の指標として葉数もしくは分 化葉数を用いることが適切であるとしている。 こ机らの報 告のように花芽分化を回避しつつ生産を成立させる生育量 が存在すると考觉られる. 緑植物春化型のタマネギやネギ の栄養成長から生殖成長への生育相転換の生育量の指標之 しては, 葉鞘径 (安藤ら, 2002; 本間ら, 1999; 白岩ら, 2005; 宾戸・斉藤, 1976）や葉齢（Brewster, 1985; 伊藤, 1956a, b）の報告がある. タマネギに拈いても，花芽分化 に必要となる生育量に相当する葉数を明らかにしたら兄 で，当該葉数に到達する期間を積算温度から推定すること により, 抽苔を避けるための播種日が算定可能となる可能 性がある。

\section{摘 要}

タマネギの葉数は, りん茎重の大きさに関わり，収量を 構成する重要な要素である。，そこで, タマネギの葉数を積 算温度から推定することを目的として，三角法などの積算 温度の計算方法を比較した。 さらに，播種日や作型の違い 扣よびリン酸の全層施肥と直下施肥の条件下に打いて回帰 式の適合度を検証した。 その結果, 基準温度を $3.5^{\circ} \mathrm{C}$ も 
くは $5.0^{\circ} \mathrm{C}$ とた三角法や平均気温法を用いた場合の推定 精度は，基準温度を $0^{\circ} \mathrm{C}$ とした平均気温の積算値を用い た場合を上回った，基準温度を設定した場合，決定係数 は，基準温度 $3.5^{\circ} \mathrm{C}$ とた場合より $5.0^{\circ} \mathrm{C}$ とた回帰式で 高かった. 從って基準温度を $5.0^{\circ} \mathrm{C}$ とし平均気温法と三 角法の回帰式は決定係数が高く, RMSE も小さいことが明 らかとなった。 また，作型を異にする場合には，基準温度 を $5.0^{\circ} \mathrm{C}$ とた平均気温法の精度が高かった. 以上のこと から播種日や作型を異にしても安定的に推定精度が高い回 帰式は，基準温度を $5.0^{\circ} \mathrm{C}$ とた平均気温法であると判断 できた。ささらに他品種や他地域での検討を必要とするが, タマネギは, 回帰式の係数により基準温度 $5.0^{\circ} \mathrm{C}$ とた積 算温度 $100^{\circ} \mathrm{C}$ ・日当たりに約 1.5 枚の展葉が認められるこ とが示唆された。

謝 辞 岩手県農業研究センタ一横田啓博士には, 三角 法の算出方法について適切な助言を与えていただきまし た. 農業・食品産業技術総合研究機構中央農業研究セン タ一細野達夫博士には, 基準積算温度の算出方法, およ び，適切な助言を与えていただきました，記して御礼申し 上げます。

\section{引用文献}

安藤利夫 ・甲田暢男・大越一雄. 2002. 初夏どりネギ栽培 に打忊る晚抽性品種の花芽分化, 抽苔特性. 千葉農総 研研報. 1:13-23.

青葉 高. 1951. 玉葱の葉数及び摘葉と球重との関係. 山 形県立農林専門学校研究報告. 4: 27-34.

青葉 高. 1964 . タマネギの球形成および休眠に関する研 究. 山形大紀要 (農). 17: 1-363.

Bierhuizen, J. F. and W. A. Wagenvoort. 1974. Some aspects of seed germination in vegetables. 1. The determination and application of heat sums and minimum temperature for germination. Sci. Hortic. 2: 213-219.

Brewster, J. L. 1985. The influence of seedling size and carbohydrate status and of photon flux density during vernalization on inflorescence initiation in onion (Allium cepa L.). Ann. Bot. 55. 403-414.

Brewster, J. L. 2008. Onion production. p. 252-256. In: Brewster, J. L. (ed), Crop production science on horticulture. Vol. 15. Onions and other vegetable alliums, 2nd edition. CABI Publishing, Wallingford, UK.

Brewster, J. L., P. J. Salter and R. J. Darby. 1977. Analysis of the growth and yield of overwintered onions. J. Hort. Sci. 52: 335-346.

広田知良. 2017. 2016 年の北海道に拈ける台風による農 業被害. 農業拈よび園芸. 92: 804.

本間利光・江村 学 - 船越昭夫. 1999. 新潟県に括ける秋 まきねぎの花芽分化と抽苔について，新潟農総研報. 1: 13-23.
伊藤 潔. 1956a. 玉葱の抽苔に関する研究（第 1 報）分 球と花芽分化の関連性について. 園学雑. 25: 187-193.

伊藤 潔. 1956b. 玉葱の抽苔に関する研究（第2 報）花 芽分化温度について. 園学雑. 25: 243-246.

Lancaster, J. E., C. M. Triggs, J. M. De Ruiter and P. W. Gandar. 1996. Bulbing in onions: Photoperiod and temperature requirements and prediction of bulb size and maturity. Ann. Bot. 78. 423-430.

室 崇人・臼木一英・嘉見大助・杉山慶太. 2017. タマネ ギ品種に招ける早晚性と展葉数の関係. 園学研. 16 (別 1) : 147.

大沼 康・佐々木丈夫. 1993. 露地野菜の三角法による生 育予測. 東北農研. 46: 283-284.

坂神泰輔・是永龍二. 1981. 有效積算温度の簡易な新算出 法 “三角法”について. 応動昆. 25: 52-54.

白岩裕隆・鹿島美彦・井上 浩 - 坂井章浩 - 田辺賢二. 2005. 初夏どりネギ栽培に打ける花芽分化時期の液肥 が植物体の窒素レベル，抽苔および収量に及ぼす影 響. 園学研. 4: 411-415.

宍戸良洋・斎藤 隆. 1976. タマネギの花芽形成に関する 研究 (第 2 報) 花芽形成に扣ける低温感応に対する苗 の性状の影響. 園学雑. 45: 160-167.

末貞辰朗・臼木一英・室 崇人・東野裕広・川城英夫・森 田直彦・森永靖武. 2018. 播種時期とリン酸の播種条 下への局所施肥が温暖地の秋播きタマネギ直播栽培の 収量性に及汸す影響. 園学研. 17: 49-54.

臼木一英・室 崇人. 2018. リン酸直下施肥と組み合わせ た窒素・カリウム肥料の施用時期が春播き直播タマネ ギの生育・収量に及ぼす影響. 園学研. 17: 405-413.

臼木一英・室 崇人・辻 博之・竹中 畺. 2016. 黒ボク 土固場のタマネギ（Allium cepa L.）直播栽培における 種子直下のリン酸局所施用がリン酸吸収扣よび初期生 育・収量に及洔す影響. 園学研. 15: 241-246.

臼木一英・室 崇人・辻 博之・竹中 眞. 2017. 火山灰 土壤での「播種条下局所施用」によるタマネギ直播栽 培に打けるリン酸肥料減肥法. 土肥誌. 88: 42-47.

Wagenvoort, W. A. and J. F. Bierhuizen. 1977. Some aspects of seed germination in vegetables. II. The effect of temperature fluctuation, depth of sowing, seed size and cultivar, on heat sum and minimum temperature for germination. Sci. Hortic. 6: 259-270.

Watanabe, N. 1978. An improved method for computing heat accumulation from daily maximum and minimum temperatures. Appl. Entomol. Zool. 13. 44-46.

山崎 篤・田中和夫. 2005. ネギの抽だい及ぼす窒素の影 響. 園学研. 4: 51-54.

山崎 篤・山本岳彦・松尾健太郎. 2015. 春まきタマネギ に拈ける葉の構成について。東北農研. 68: 123-124. 